\title{
Language Errors in Public Advertisement
}

Annisa Khusnul Khotimah

(Program studi Bahasa Inggris, Fakultas Ilmu Pendidikan Universitas MH. Thamrin)

\begin{abstract}
Language Errors in Public Advertisement. Key words: language error, public advertisement

Advertisement is the media that have strong power to convey any message. The use of English inappropriately makes their message unclear and fail to be perceived by people as the reader. This article shows the levels of error based on James in his Errors in Language Learning and Use. The errors found in advertisements mostly are in lexical level, morphological level, and syntax level. The advertisements publisher should understand the English grammar and vocabulary before they create the message on the board in English.
\end{abstract}

\begin{abstract}
ABSTRAK
Kesalahan Bahasa pada Iklan Ruang Terbuka . Kata Kunci: kesalahan bahasa, Iklan-Iklan Ruang Terbuka

Iklan adalah media yang memiliki kekuatan yang kuat untuk menyampaikan pesan apapun. Penggunaan bahasa Inggris tidak tepat membuat pesan mereka jelas dan gagal dimengerti oleh orang-orang sebagai pembaca. Artikel ini menunjukkan tingkat kesalahan bahasa berdasarkan James dalam bukunya berjudul Kesalahan dalam Pembelajaran Bahasa dan Penggunaan. Kesalahan yang ditemukan dalam iklan sebagian besar berada di tingkat leksikal, tingkat morfologi, dan tingkat sintaks. Penerbit iklan harus memahami tata bahasa Inggris dan kosa kata sebelum mereka membuat pesan di papan dalam Bahasa Inggris.
\end{abstract}




\section{Introduction}

Nowadays is globalization era. English is needed to improve and build a better life. It is because English almost become an important language in work field. English as an international language spreads all over the world. Indonesian people sometimes appreciate English inappropriately. Many of us are proud of English and regard it as modern language. Since there are foreign people who live and work in Indonesia, Indonesian people consider the importance of English used in media to convey their message and purpose.

Advertisement is the media that have strong power to convey any message. As Wright, Winter \& Zegler (1982: 8) in Wirdasari (2011:7) stated the function of advertising can be viewed in two basic ways: as a tool of marketing and as a means of communication. Then the message can be perceived broadly and consumed directly by society if it is on public/outdoor advertising. Advertisements spread along main roads and roadside. We see them in many kinds of form and style every day. In addition, outdoor advertising has seen a growth spurt over the past in Indonesia and is heavily concentrated in Jakarta, the capital city (The Report Indonesia, 2008: 201).

Many Indonesian people in Jakarta who have important role in society insert English in their public message. In fact, they use English on the whole public messages although the majority readers are Indonesian people. They give information and prohibition, and persuasion of a company too. It is an ironic that there are still many Indonesian people who do not understand English well. The problem comes from the writer or the publisher of the advertisements himself who determine whether his message is perceived by the readers or not

If we take a look at many written advertisements in Jakarta and its surroundings, we will find many errors English messages written on those society products. According to Hassal in Parikesit on http://netsains.com/2010/05/indonesia-vis-a-vis-barat-konfrontasi-domestifikasi-atau harmonisasi/, retrieved on April 6, 2011, Bahasa Indonesia has gradually adopted the grammar of English. The errors on them are usually about the grammatical structure, the choice of words, the mix of them and the mix of Bahasa Indonesia and English. According to Hassal on http://www.bahasakita.com/articles/english-ischanging-the-grammar-of-indonesian/, retrieved on April 6, 2011, this is not a new thing for Indonesia for the last century or so it has been absorbing new English-type structures. Some of us aware of those errors, but the rest (the majority people) are not. The consequence is that the majority of people who do not understand English well and who are not aware of it have not cared about those errors since many years ago.

We do not understand what the message means. Some interpretations will congest in our brain to decide what the best meaning of the message. Indeed, we perceived the message as what it is read although the real message is not as what we perceived. The advertisements publisher should understand the English grammar and vocabulary before they create the message on the board in English. If they want to convey message in English, they should pay attention on the English grammar and the choice of words without any native language influences so that they can convey their messages successfully and the readers can perceive the message well. It is because as Crew (1977: 6) in James (1998: 42) for formal written purposes where communication is paramount the more neutral international standard should be adopted, which is the system prevailing in Britain and the U.S.A.

Error in writing advertisements is one of big problem in second language acquisition, in term of linguistics especially. Based on previous study of error analysis in public advertisements in Jakarta and it's surrounding by the same writer of this article, there are errors $31,65 \%$ in lexical level, $18,99 \%$ in morphology level, and 49,37\% in syntax level. This article uses Errors in Language Learning and Use by Carl James to show the levels of error in language. The benefit of this article is informing the reader the levels of language error found in public advertisements.

\section{Discussion}

James (1998, 130-161) divides errors in five levels. They are substance errors, text errors, lexical errors, grammar errors, and discourse errors. 


\begin{tabular}{|c|c|c|}
\hline No. & $\begin{array}{l}\text { Level of } \\
\text { Error }\end{array}$ & Scope \\
\hline 1. & $\begin{array}{l}\text { Substance } \\
\text { Errors }\end{array}$ & Misspellings and mispronunciations \\
\hline 2. & Text Errors & $\begin{array}{l}\text { Widdowson (1995: 164) in James (1998: 142) defines that } \\
\text { texts can come in all shapes and sizes: letter, sound, word, } \\
\text { sentence, combination of sentences. }\end{array}$ \\
\hline \multirow[t]{5}{*}{3.} & \multirow[t]{5}{*}{$\begin{array}{l}\text { Lexical } \\
\text { Errors }\end{array}$} & $\begin{array}{l}\text { Word misselections: consider }[\text { able }] / \text { consider }[\text { ate }] \text { and } \\
\text { prize/price }\end{array}$ \\
\hline & & $\begin{array}{l}\text { Word misfromations: words that are created from MT } \\
\text { influence or TL sources: e.g. insered (means included from } \\
\text { Portuguese L1 inserido) and sleep suit (means pyjamas } \\
\text { from German L1 Schlafanzug) }\end{array}$ \\
\hline & & $\begin{array}{l}\text { Word distortions: words are created without L1 resources: } \\
\text { e.g. omission inter(e)sting, overinclusion fresh(er)men, } \\
\text { din(n)ing room, misselection delitouse (from delicious), } \\
\text { misordering littel (from little), blend starps (from star + } \\
\text { stop) }\end{array}$ \\
\hline & & $\begin{array}{l}\text { Confusion of sense relation: e.g. meaning between big and } \\
\text { great }\end{array}$ \\
\hline & & $\begin{array}{l}\text { Collocational errors: companion or combination of each } \\
\text { word: e.g. heavy losses (not big losses) or fish and chips } \\
\text { (not chips and fish) }\end{array}$ \\
\hline \multirow[t]{2}{*}{4.} & \multirow[t]{2}{*}{$\begin{array}{l}\text { Grammar } \\
\text { Errors }\end{array}$} & $\begin{array}{l}\text { Morphology errors: N ten pencil (not ten pencils), V meeted } \\
\text { (not met), Adv latterly (not later), A wonderfuler (not more } \\
\text { wonderful) }\end{array}$ \\
\hline & & $\begin{array}{l}\text { Syntax Errors: } \\
\text { a. Phrase structure errors: errors happen in NP, VP, } \\
\text { Ajp, AvP, PP: e.g an ugliest man (error of article in } \\
\text { NP). } \\
\text { Other errors in DP (Determiner Phrase), IP } \\
\text { (Inflectional Phrase), QP (Quantifier Phrase), CP } \\
\text { (Complementizer Phrase): e.g. I know girl (error of } \\
\text { article omission involving DP: head of the, in NP) } \\
\text { b. Clause errors involving phrase errors in a clause. } \\
\text { c. Sentenceerrorsinvolvingselectionand } \\
\text { combination of clauses in a sentence. } \\
\text { d. Intersentence errors: cohesion }\end{array}$ \\
\hline 5. & $\begin{array}{l}\text { Discourse } \\
\text { Errors }\end{array}$ & Coherence in the content of discourse. \\
\hline
\end{tabular}

Advertisements language often consists of only some sentences, phrases or only some words. Therefore error level used in advertisements includes lexical level (LL), morphological level (ML), and syntax level (SL), such as one of advertisements consisting errors below.

\begin{tabular}{|c|c|c|c|c|}
\hline $\begin{array}{c}\text { Sample of } \\
\text { Advertisement } \\
\text { and Error Location }\end{array}$ & LL & M L & SL & Revised \\
\cline { 2 - 4 } & & & & \\
\hline
\end{tabular}




\begin{tabular}{|c|c|c|c|c|}
\hline \multirow{2}{*}{$\begin{array}{c}\text { Sample of } \\
\text { Advertisement } \\
\text { and Error Location } \\
\end{array}$} & \multicolumn{3}{|c|}{ Error Level } & \multirow{2}{*}{$\begin{array}{c}\text { Revised } \\
\text { Error }\end{array}$} \\
\hline & $\overline{\mathrm{LL}}$ & $\mathrm{ML}$ & $\overline{\mathrm{SL}}$ & \\
\hline $\begin{array}{l}\text { Headline: } \\
\text { Beauty and Fresh }\end{array}$ & $\begin{array}{l}\text { The slogan } \\
\text { "Beauty and } \\
\text { Fresh"e consist of } \\
\text { different lexical } \\
\text { category } \\
\text { words. Beauty is a } \\
\text { noun while fresh } \\
\text { is an adjective. If } \\
\text { the publisher } \\
\text { wants the } \\
\text { emphasize the } \\
\text { effect of having } \\
\text { treatment in that } \\
\text { salon, he should } \\
\text { use adjectives: } \\
\text { Beautiful and } \\
\text { Fresh. }\end{array}$ & \begin{tabular}{|l|} 
The error in \\
choosing \\
different \\
form of \\
word in \\
parallel \\
sructure is a \\
morphology \\
error, like \\
beauty and \\
beautiful.
\end{tabular} & $\begin{array}{l}\text { It } \quad \text { is } \\
\text { misform } \\
\text { ation of } \\
\text { a head } \\
\text { of NP. }\end{array}$ & $\begin{array}{l}\text { Beautiful } \\
\text { and } \\
\text { Fresh }\end{array}$ \\
\hline
\end{tabular}

\section{Conclusion and Suggestion}

This study shows the levels of error in public advertisements as the important media for conveying message. The main causes of the errors are, of course, the interference of native language (Bahasa Indonesia), less English knowledge of the publishers, and the complexity of English. Moreover, we get the causes of the errors in detail, in terms of lexicology, morphology and syntax. Errors can be at the level of phrase because they are in the position of head or modifier in phrases. Then, since the errors are never corrected, many people imitate the error for other English use. Word selection and word order have big role for the successful advertisement.

The writer suggests the reader and English Department student especially to conduct another Error Analysis both in pedagogic and non pedagogic field. It is because error analysis is the most important empirical method to get information about the function of cognitive process in language production and language perception as the source of knowledge for linguist (Spillner, 1991: xi). This study will be conducted well with good knowledge of linguistic study, such as lexis, syntax, and morphology.

\section{Bibliography}

Hassal, Timothy. 2010. English is Changing The Grammar of Indonesian. From http://www.bahasakita.com/articles/english-is-changing-the-grammar-of-indonesian/, 1 May 2011 James, Carl. 1998. Errors in Language Learning and Use. England: Longman. Parikesit. Arli Aditya. 2010. Indonesia vis a vis barat: Konfrontasi, Domestifikasi, atau Harmonisasi?.

From http://netsains.com/2010/05/indonesia-vis-a-vis-barat-konfrontasi-domestifikasi-atau-harmonisasi/. 19 May 2011.

Spillner, Bernd. 1991. Error Analysis: A Comprehensive Bibliography. Amsterdam: John Benjamins B.V.

The Report Indonesia (2008). Oxford Business Group. Wirdasari, Meitya. 2011. The Language of Comestics Advertisements in Women's Magazine U.S.

Cosmopolitan Magazine. Thesis. Jakarta: English Department of Universitas Negeri Jakarta. 
